\title{
PERMANENT REVOLUTION: A SCHIZOANALYTIC PHILOSOPHY OF THERAPEUTIC AND REVOLUTIONARY TRANSFORMATION
}

\author{
Raniel S.M. Reyes \\ Philosophy Department, University of Santo Tomas \\ Philippines
}

\begin{abstract}
In this article, I present a critical exposition of and engagement with Gilles Deleuze and Felix Guattari's schizoanalysis, and its therapeutic and revolutionary powers. Firstly, I discuss how the aftermath of the May 1968 phenomenon shapes the formulation of schizoanalysis, specifically, in relation to the French people's desire for voluntary servitude to what they call as 'State philosophy.' More importantly, I discuss desire's social investment, syntheses, and parallogisms. Secondly, I elucidate schizoanalysis' goal of achieving freedom from all kinds of Oedipalizations and capitalist exploitations from the family to the society writ large. In this regard, it is schizophrenia which is capable of subverting all forms of oppressions or totalizations fabricated by Oedipus and capitalism. Lastly, I explicate schizoanalysis' aim, which is to reinstate desire's revolutionary potentialities toward a revolution fueled by "schizophrenia as a process," which Deleuze and Guattari call as 'permanent revolution.'
\end{abstract}

\section{N T RODUCTION}

Aside from the celebrated May 1968 event, Gilles Deleuze and Felix Guattari's schizoanalysis is greatly informed by Classical Marxism, Leninism, and the Bolshevik Revolution, to name a few. Nevertheless, while the concept of the Communist revolution generally informs their sociopolitical imagination, they renounce its proletarianization and teleological trajectory, in favor of a micropolitical theorization of a revolution-tocome. ${ }^{1}$

Deleuze and Guattari repudiate the possibility of a global revolution against totalitarian and capitalist-manipulated States whose goal is to end up all contradictions in society. Likewise, they negate any kind of grand or macropolitical struggles that would convert ethical fascism into molecular investments of desire. For them, it is imperative to launch a micropolitical diagnosis of the existence of fascism (famously 
represented by capitalism) in contemporary institutions, as well as in the manifold networks of political and subcultural enunciations.

\section{SCHIZOANALYSIS: AN IMMANENT THEORY OF DESIRE AND CRITIQUE}

\section{The Pathologization of Desire and Anti-Oedipus}

The Anti-Oedipus (Gilles Deleuze and Felix Guattari 1983, xvi) primarily seeks to reconstruct Wilhelm Reich's query in relation to the rise of fascism in the 20th century: How could the masses be made to desire their own oppression? Foucault echoes Reich's claim in his "Preface" to aforesaid book and describe this predicament as "the fascism in all of us ... the fascism that engenders the masses to desire their own exploitation" (Deleuze and Guattari 1983, xiii). In other words, the main task of schizoanalysis is to investigate and analyze the conditions that engender people to desire oppression or Oedipus.

This philosophic challenge presupposes that previous scholarship fails to bridge the gap between the Freudian concept of libido and the Marxian notion of labor-power. Marxism's historico-economic reduction fails to perceive that oppression in the current scheme of things is no longer class-based, that the revolution is not anymore proletarianized, and more importantly, that mass psychology or libido is indispensable in conducting a comprehensive and timely social analysis or critique. Presently, fascism operates outside the terrains of party-politics and historical materialism. It is a lifetypology that causes people to submit themselves to exploitation. Dominant theories before the May 1968 student revolt, like Marxism, fell short in recognizing how psychic repression is caused by or inextricably related to societal domination.

Further, Deleuze and Guattari's historicization of Freud accentuates social oppression as the sole determinant of psychic repression. Social oppression bears a plethora of appearances and consequently influences psychic oppression intermittently. Likewise, they argue that Marxism and psychoanalysis must be revised to have a better theorization of subjectivity and to become more dynamic in relation to sociohistorical contingencies, respectively (see Deleuze and Guattari 1983, xiii). In schizoanalysis, psychic repression distinctively involves the workings of the unconscious. However, it does not imply that it is comprehensible and isolated from social repression. Psychic repression exists because social repression is desired.

The problem of desire is neither a sole quandary of Marxism nor psychoanalysis. The marriage between psychiatry and politics espoused by schizoanalysis provides reflective and extensive resources to explain why the May 1968 protest occurred and how psychic repression is related to social domination and vice-versa. ${ }^{2}$ This enables Deleuze and Guattari to conceptualize their philosophy as an attack against all reductive psychoanalytic and sociopolitical analyses configured under the principle of totality or Oedipality, toward a revolutionary theorization of desiring-production. Their philosophic project problematizes how to introduce desire into discourse and action, and how the 
forces of desire can be deployed within the political realm to dismantle the exploitative frontiers of the status quo (Deleuze and Guattari 1983, xii).

Schizoanalysis is primarily a polemic against orthodox psychoanalysis' reductive appropriation of desire. At this point, let me elaborate what Deleuze and Guattari mean by 'reductive psychoanalysis.' Dismissing any nonsexual human behavior as a kind of sexual perversion is one of the reductive features of conventional psychoanalysis. Rather than desexualizing or sublimating desire, they claim that sexuality exists ubiquitously in the social milieu. Their pronouncement that 'sexuality is everywhere,' furthermore, is a liberation from Freudian psychoanalysis where sex is simply reduced to an anthropomorphic concept (see Deleuze and Guattari 1983, 294). In fact, the object of desire recognizes no anthropological boundaries for it deals with the entire "surroundings which it traverses, the vibrations and flows of every sort to which it is joined and in which it introduces breaks and captures" (Deleuze and Guattari 1983, 294).

Deleuze and Guattari employ the 'factory model' of desire instead of the theater model as a critique of representation. The said model grounds their positive theorization of desire that revolutionizes the whole Western philosophical tradition, which merely considers it as a lack or need. ${ }^{3}$ Their schizoanalytic project elucidates the affirmative potentialities of desire in relation to its marginalization in Psychoanalysis and Marxism. Primarily, desire in Deleuze and Guattari's schozoanalysis is illustrated as a first-order active force, not a slavish response to unsatisfied need as presented in traditional Western scholarship. Desire actively produces connections, constellations, and intensities (see Deleuze and Guattari 1994, 77). Sadly, since the time of Plato, desire is limited to an unremitting, if not insuperable, goal in retrieving a missing object of satisfaction.

The formula of desire as lack is constitutive of two binary terms, namely the desired object and the desiring subject. Psychoanalysis appropriated these two terms by theorizing the essential lack of desire to be a pre-condition of subjectivity formation. The child breastfed by the mother, with all needs gratified, lacks a sense of self, world, and difference. It is only when the baby learns to escape from this fulfilling experience or the desired origin that subjectivity emerges In the lens of psychoanalysis, as desire tries to surmount all kinds of lack, aversions, and differences, it likewise prepares its own deathbed. In this vein, the death drive actualizes as the essence of subjectivity that accentuates psychoanalysis' reductive interpretation of desire.

On the contrary, what desire lacks is a fixed subject. A fixed subject is fashioned through repression. In the case of desire's configuration as a lack, its representation is a kind of repression that distorts or obliterates its capacities. In fact, when we think of an individual or any human organization, desire is already repressed. Repression incapacitates the subject to capitalize its machinic attributes, i.e., to connect to other machines and establish perpetual constellations. In other words, desire is a machinea nomadic machinery. Because of repression, its dynamism is segmented or is detached from the incessant flow of life.

Further, desire is not about the external relation between the binaries of the desiring subject and the desired object. Desire is production itself. Like sexuality, it is beyond 
the anthropomorphic configurations constructed by traditional Western philosophizing. Philosophical anthropomorphism and its foremost valorization of the "white rational man" only become possible because of the coding of the flows of desire into various organisms. In fact, the plane of immanence is composed of desire in the form of rhizomic flow of becoming and relations. This optimization of the capacities of desire frees it from representation (as lack, essential to the formation of subjectivity, and as anthropological). Consequently, we are left with our experience of the duration and encounters of bodies, not limited to the human. What is desired is a pre-individual 'germinal influx of intensity' (Deleuze and Guattari 1983, 164). The fecund, impersonal, and differential characteristics of desire transform it as intrinsically revolutionary capacitated to dismantle all kinds of oppressive and dogmatic systems.

Because desire bears the intrinsic capability in crafting connections and reality, then psychoanalysis' claim that it must first be sublimated to be part of the social field is nullified by Deleuze and Guattari $(1983,31)$ : "We maintain that the social field is invested by desire, that it is the historically product of desire, and that libido has no need of any mediation or sublimation ... in order to invade and invest the productive forces and the relations of production."

If the concept 'object' or 'objective' has a place in schizoanalysis, it is in the form of a critique of Oedipalized or stratified organizations. These organizations estrange desire from its objective and protean existence because creative becomings are homogenized by State philosophy and other representationalist principles. ${ }^{4}$ Doubtless, the revolutionaries and artists receive noble admiration from Deleuze and Guattari. Despite multifaceted pressures from society, they manage to maintain a certain kind of criticality and objectivity (see Deleuze and Guattari 1983, 27). Indeed, desire has a crucial role in revolution (becoming-revolutionary) and in society. More importantly, desire, as Paul Patton $(2000,70)$ profoundly asserts, "must be understood to embody the power of differential reproduction or becoming-other which is the condition of creativity in culture, as well as in nature."

\section{Schizoanalytic Critique of Oedipus and Capitalism}

Anti-Oedipus aims to fulfill the promise of Kant's critique through the replacement of conventional psychoanalysis (i.e., Freudian and Lacanian) toward a revolutionary materialist psychiatry (schizoanalysis). The utilization of the schizoanalytic model of desire depicts the psyche as an assemblage of desiring-machines. For a comprehensive understanding of the nature of desiring-machines, it is important to explain how it operates based on the three syntheses of desire, namely the connective synthesis of production, the disjunctive synthesis of recording, and the conjunctive synthesis of consumption-consummation.

The connective synthesis of production is derived from the Freudian concept of drives, cathexis, and polymorphous perversity. Productive desire is intrinsically connective. The production of connections made in the connective synthesis, corresponds to Freud's concept of drives, which forms part the materialist basis of the model (see Eugene Holland 1999, 26). Moreover, the first synthesis merely connects 
partial-objects, not whole organs or persons.

Meanwhile, the disjunctive synthesis of recording initially deals with the psyche as a recording apparatus of past objects of satisfaction. The utilization of the Freudian characterization of the psyche aspires to criticize psychoanalysis' fixation to the Oedipus complex. ${ }^{5}$ The disjunctive syntheses of desire, moreover, necessitate a counter-force that would complement it with the first syntheses - 'anti-production.' As a neutralizing principle, it either halts or freezes the rampaging current of connections. Rather than merely being a passive spectator of the connective synthesis' productivity, antiproduction stops preexisting organ connections to craft new ones (see Deleuze 1990, 208). It also desexualizes desire, which then constitutes a recording surface where networks of relations are registered.

The novel dimension of desire elicited from anti-production (disjunctive synthesis of recording) facades Deleuze and Guattari's formulation of the Body-without-Organs (BwO). ${ }^{6}$ Although the term $\mathrm{BwO}$ is borrowed from Antonin Artaud (2015), the question of the composition of individuals using the body as the model of philosophizing goes as far as their Spinozist and Nietzschean lineages. They circumvent the essentialist question of "what is the body?" by focusing on how the body differentializes itself to affect other bodies and to be affected perpetually. The kinetic and expressionist attributes of the body nullify any attempt to conceive it as an organism characterized by a priori and immutable attributes. This explanation initially grounds the Deleuzo-Guattarian theorization of the BwO.

In relation to the production of desire, $\mathrm{BwO}$ is conceptualized in conjunction with the problem of how the body is organized and disorganized to fashion other kinds of organizations. The noble importance of anti-production's disorganizing aptitude is its repulsion of the possibility of desiring-production to be fixated only to a single organmachine or relation. Consequently, the connective synthesis of production transforms into the disjunctive synthesis of recording. This experience, which is recorded in the $\mathrm{BwO}$, entails a kind of liberation from the preexisting relation toward new ones openendedly, where the baby, for instance, looks for another organ-machine connection.

After the signs of machinic connections are registered in the $\mathrm{BwO}$, it provides a surface that harmonizes repetition and memory, which subsequently mobilizes individuals to iterate mode of desiring-satisfaction in the past, with either superior or inferior quantity or quality of freedom of variation within repetition (see Holland 1999, 29). The intermittent relation between desiring-production and anti-production ushers the organ-machines and the BwO into a multiplicitous, synchronic, and polyvocal existence. Despite the detrimental consequence produced via the annihilating or interruptive power of antiproduction, it has the positive dimension of opening up to new types of relations. Therefore, the $\mathrm{BwO}$ can illustrate a potentiality for freedom. Notwithstanding this emancipatory potential, its anti-productive spirit can engender the total breakdown of connections and organizations. Because there is no guarantee whether disorganization would prevail over organization or vice-versa, the repulsion of preexisting relations can be internalized as a kind of repression (neurosis or self-denial), which reminds us of Freud's 'primal repression. ${ }^{.7}$ If all existing connections are withdrawn and new organ-machine 
connections are no longer established, it can lead to the full existence of the $\mathrm{BwO}$, where individuals enter the state of 'catanoia' that is usually the authorship of capitalism's vehement refusal to countenance (see Deleuze 1990, 189). ${ }^{8}$

The dominance of one kind of production over the other greatly depends on the prevailing mode of social production, and whether individuals would relate to it actively or reactively. But aside from the formations and breakdowns generated from desiringproduction and anti-production's antithetical relationship, the interplay between them can also engender various forms of subjectivity in the stage of conjunctive synthesis consumption-consummation. This stage is indispensable because of its power to dispossess the subject from becoming hubristic. Rather than being a metaphysical concept, the subject simply appears as a result of the selective process rendered by desire among manifold connective and disjunctive syntheses. The subject is merely an outcome of the connection and disjunction initiated by desire in the BwO. Thus, for Deleuze and Guattari, traditional Western philosophy's hubristic conception of the sovereign or transcendental subjectivity consciously and wholly responsible for all its choices and pleasures, is nothing but a whimsical idea. If ever the subject recognizes its constitution, it is only through retrospective thinking - "That was me."

The three syntheses of desire comprise the dynamic configurations of the schizoanalytic model of the psyche or subjectivity. The formulation of this DeleuzoGuattarian brand of subjectivity is primarily conditioned by the reactive dominance of Oedipal subjectivity in the study of the psyche (individual and societal). The Freudianauthored concept serves as the nerve-center of the nuclear family under capitalism. It operates based on a systematic yet illegitimate utilization of the very syntheses of desire that make schizoanalytic subjectivity possible. ${ }^{9}$

Generally, Freudian psychoanalysis appropriates the Oedipus complex as the child's prohibition to marry his mother and to murder his father. This theory is flawed because its conclusion is directly a derivative of the prohibition against incest. ${ }^{10}$ In this circumstance, desire is trapped in the paralogism of displacement. Desire is presented with a fabricated image of its object of desire by virtue of the Oedipus complex in the very activity of prohibiting it. As individuals come to discover what they want in life, they suddenly realize that these things are beyond their grasp. The falsified image of desire's inaccessible object authored by Oedipal prohibition represses desire because it is created to trap desire's revolutionary potentialities.

The paralogism of displacement is a significant microcosm of fixed representations that distort the dynamism of desire. But let me highlight that the distortion of desire is something inevitable. The $\mathrm{BwO}$ is a neutral surface that records productive connections as signs. Its ambivalence opens desire for possible distortion, fixation, and variation (see Deleuze and Guattari 1983, 339).

Further, schizoanalysis understands the nuclear family as an assemblage of social practices and discourses. In the yardstick of schizoanalysis, the nuclear family can be paralleled to psychoanalysis' system of representation, as well as its appropriation of the Oedipus complex. Similarly, Deleuze and Guattari assert that it is psychoanalysis that fortifies the nuclear family's objective movement under the capitalist society. But 
this explanation does not entail that they accuse psychoanalysis of creating Oedipus. In the nuclear family, desire is recorded as Oedipalized in the BwO. Its representationalist recording halts desire's dynamic capabilities that thereby ground the production of Oedipalized subjects. However, the nuclear family, as a capitalist-configured institution, is not beyond critique. Although it assumes a so-called transcendental appearance, psychoanalysis is a historically configured institution of production. Despite its capitalist capture, its historico-material specificities open the windows for psychoanalysis' selfcriticism that would further lead to Oedipus' overthrow.

Moreover, the nuclear family is an institution responsible for the creation of fixed and myopic subjectivities - contrary to the nomadic subject produced in the conjunctive synthesis. The belief of fixed subjectivity adheres to the metaphysical illusion of sovereign subjectivity. The fixed subjectivities emerging from the nuclear family apparently manifest the paralogism of the illegitimate use of the conjunctive synthesis. One notable adverse effect of this paralogism is that the subject is deprived of its nomadic nature. Likewise, it isolates the subject from other subjectivities. In history, we witness how this restrictive blunder authors different forms of totalizations and exclusions such as religious fundamentalism and cultural imperialism.

In nomadic subjectivity, identities are democratized and are perceived to be inseparable and dynamically related to the collective whole. On the contrary, in Oedipal subjectivity, individuals become hubristic as they believe to be part of a privileged group such as the Christians, the white people, and the male phallus (see Deleuze and Guattari 1983, 103). The more individuals imbibe this delusional or ideological sentiment, the more Oedipus strengthens.

Capitalism consciously individuates Oedipal subjects in the nuclear family from other social mechanisms for their identities to be restrictively patterned before the mother (the prohibited object of desire) and the father (the agent of desire).${ }^{11}$ Increased illegitimate use of the conjunctive synthesis and reproduction of myopic subjectivity in the family means increased manipulation and marginalization. Unfortunately, the more individuals are denied of their exterior relations, the more they are enfeebled and the more desire's revolutionary potentialities are corrupted.

The aforesaid disquisitions confirm Deleuze and Guattari's position that individual repression cannot be holistically analyzed independent from societal repression. The nuclear family is neither a microcosm of the society nor an independent institution. Like the body, it serves as a conduit of sociohistorical determinations. While psychoanalysis misrecognizes this fact, capitalism erects rigid walls around its territory and creates a fabricated notion of desire and subjectivity to safeguard its incessant domination and amplification. Highlighting such a capital mistake of psychoanalysis and viciousness of capitalism elicits another illegitimate use of the conjunctive syntheses - the bi-univocalization of subjectivity. This process reduces the polyvocal attributes of nomadic conjunctions and contingencies. It likewise totalizes the complex and rhizomic terrains of the unconscious.

The two paralogisms incarcerate desire in binary hierarchies, thereby segregating subjectivities into privileged and marginalized groups. The homogenization of desire is 
aggravated in the nuclear family because its aptitude is limited to the Oedipal triangulation. The prohibitor-prohibited paradigm of the mother and the father eventually translates into the oppressor-oppressed rubric. The nuclear family estranges psychoanalysis in the sense that Oedipal subjectivity reduces everything in to Oedipal triangulation (paralogism of application). All contingencies and nuances of social materialities are converted into bi-univocal interpretations. In other words, all are oversimplified into an Oedipal problem, regardless of the complexities of societal productions. On the contrary, schizophrenic subjectivity legitimately utilizes the disjunctive synthesis. It affirms other possibilities beyond Oedipus Complex's blinkered territories and mobilizes subjectivity beyond the Oedipal double-impasse. It is true that the father-mother model remains as one of the identity-determinations of the schizo or nomad. But they must not get fixated with it because such an Oedipal pattern is only one among the conduits of desire, such as the animals, plants, and other forms of human collectivities.

From the family, let us now turn to gender distinctions - the very concept by which Lacanian psychoanalysis is guilty of the illegitimate use of the disjunctive synthesis because it limits gender distinctions into either male or female. ${ }^{12}$ For Deleuze and Guattari, sexuality is irreducible to either aforementioned identities or even to homosexuality or heterosexuality. Schizoanalysis, they claim, "is the variable analysis of the $n$ sexes in a subject, beyond the anthropomorphic representations that society imposes on this subject, and with which it represents its own sexuality" (Deleuze and Guattari 1983, 296). Instead of succumbing to the limiting configurations of Oedipus, they introduce the concept 'trans-sexuality.' Briefly, this new concept affirms a multiplicity of differences beyond Oedipal and anthropomorphic representations. Subjectivity is transsexual when it has the aptitude of becoming-other.

Writ large, disjunctive synthesis is legitimately abused when it encourages exclusivity rather than inclusivity; i.e., it discriminately limits the kinds of possible satisfaction for the multifaceted drives it differentiates. The illegitimate use of the disjunctive synthesis breeds the illegitimate use of the connective synthesis or the paralogism of extrapolation. One of its negative effects is the bi-univocalization of free-association authored by psychoanalysis. Ideally, free-association portrays a legitimate usage of the connective and disjunctive syntheses. Unfortunately, conventional psychoanalysis bi-univocalizes the polyvocal connections rendered by free-association, resulting in stereotype identifications or prejudiced propositions such as everything that is Western is superior and all Muslims are terrorists. It is a form of paralogism because it privileges and isolates one term over other connections or chain of associations. Thus, these terms are reified such as they transfigure into universal concepts that condition the possibilities and regulate the meanings of all the others.

The last of the five paralogisms of psychoanalysis is called the paralogism of the afterward. Like the paralogism of application, it positions the nuclear family as the regulative principle of anything sociohistorical in relation to psychic life. Sociohistorical productions and investments are demoted as sublimated forms of Oedipal relations processed within the nuclear family. Thus, Oedipal relations in the nuclear family are not primary, autonomous, and universal, in relation to sociohistorical dynamics. These 
fanatical and restrictive relations are mere delegations by capitalism in the nuclear family. Additionally, the nuclear family is not an abstract nor universal concept because it is a socio-historically constituted capitalist institution.

The five kinds of paralogisms, embodied by Oedipal psychoanalysis, excludes sociohistorical investments from the myopic and one-dimensional institution of the nuclear family. As the nuclear family appears as a sovereign institution, it strengthens its capacities as a capitalist-manipulated mechanism (see Deleuze and Guattari 1983, 99). Societal production can eventually develop and continually revolutionize itself without regard for nomadic subjectivity-formation and reproduction, as well as the direct management of their desire. Through the five paralogisms, any attempt to critically challenge and antagonize Oedipal authorities (the father or the capitalist) would always appear, in a deceitful fashion, as an incestuous initiative.

Capitalism's delegation of social repression to the nuclear family deceptively constructs a narrative that indicts the Oedipus complex as an independent source of psychic repression. However, adhering to this claim prioritizes psychic repression over social repression. Oedipal psychoanalysis' valorization of psychic repression as primary and universal, and social oppression as secondary and inevitable are reversed by Deleuze and Guattari (see Holland 1999, 57). In a non-linear manner, they ascribe the potentiality of both kinds of repression to the recording of desire in the ambivalent $\mathrm{BwO}$ initially by virtue of the primary repression engendered by anti-production. This movement emphasizes that despite the difference in nature between the two kinds of repression, genuine independence cannot be established.

Ultimately, the disquisition of the legitimate and illegitimate utilizations of the syntheses of desire seeks to subject Oedipal psychoanalysis to self-critique. Avoiding such immanent examination is acquiescing to the allegation of being oppressive and metaphysical. Schizoanalysis does not restrict itself to the critique of the nuclear family. It magnifies its critical project by highlighting that even the social milieu of production and reproduction is guilty of parallel misconducts, which necessitate its immanent diagnosis and radicalization.

\section{SCHIZOPHRENIA AND THERAPEUTIC TRANSFORMATION}

The operation of the capitalist machine is characterized by the immanent contradiction between decoding and recoding, as well as deterritorialization and reterritorialization (see Deleuze and Guattari 1983,303). Deterritorialization liberates all libidinal energies from deceptive objective codes. In doing so, desire and labor's subjective and abstract attributes are revealed. Meanwhile, reterritorialization relocates the relations of production and consumption to private ownership, or to the oppressive mechanism of Oedipus (capital). Such a contradiction, in my view, can be perceived as a kind of ambivalence. On the one hand, the process of recording halts repetitive or reactive organ-machine connections, and more importantly, emancipates desire from preexisting obsolete and unproductive relations. On the other, the freedom enjoyed by desire is ambivalent and merely ephemeral because it likewise becomes vulnerable to the repressive organizations of the capitalist socius. In the capitalist society, the 
disclosure of the abstract and subjective qualities of desire and labor is succeeded by their axiomatization. As a result, human reproduction is singled out from social reproduction in the nuclear family in the same manner that desire (desiring-production) is separated from labor (social-production).

Capitalism segregates labor from desire. The eradication of this chasm and the dynamic harmonization of these two investments actualize as the paramount goals of schizoanalysis. It transfigures desire and labor from their corresponding polarized systems of representations into the concepts of desiring-production and social production so as to accentuate their convergent genealogy from production in general and without distinction in the capitalist society (see Deleuze and Guattari 1983,302). The creative conjunction of labor and desire is inspired by the schizoanalysis' overall goal of achieving critical freedom from all kinds of repressions and capitalist exploitations be it in the molecular terrain or otherwise. Aside from its critique of Oedipus and capitalism, schizoanalysis must also be reconfigured to become "revolutionary, artistic, and analytic machines working as parts" (Deleuze 1995, 24) in order to cope with the acceleration of capitalism. But the concept 'revolutionary' is one of the most abused and misunderstood concepts in history; that is why, it is very important to know how Deleuze and Guattari $(1983,260)$ define the revolutionary path: "Is there one?-To withdraw from the world market, as Samir Amin advises Third World countries to do, in a curious revival of the fascist 'economic solution'? Or might it be to go in the opposite direction? To go still further, that is, in the movement of the market, of decoding and deterritorialization?"

Contradictions that fuel societal dynamicity are appropriated by capitalism. Societal machinic assemblages are habituated in feeding off "the contradictions they give rise to, on the crisis they provoke, on the anxieties they engender, and on the infernal operations they regenerate. Capitalism has learned this, and has ceased doubting itself, while even socialists have abandoned belief in the possibility of capitalism's natural death by attrition" (Deleuze and Guattari 1983, 151). To achieve schizoanalysis' revolutionary goal, the great challenge is to initially 'capitalize' on capitalism's immanent contradiction.

In fact, the capitalist system's propensity toward decline (falling rate of profit) is a contradiction that fortifies the system. For Deleuze and Guattari $(1983,230)$ "If capitalism is the exterior of all societies ... this is because ... [it] has no exterior limit, but only an interior limit that is capital itself and that it does not encounter, but reproduces by always displacing it." At present, capitalist deterritorialization moves from the center (developed countries, for instance) going to the margins (underdeveloped countries, for example). Capitalism undergoes schizophrenization whereby it displaces its crisis of accumulation perpetually from the center going to the periphery (see Buchanan 2008, 111). However, its capability of pushing its own limits is merely a ploy to its narcissistic aim of gaining interminable profit. In other words, as long as a particular kind of social innovation produces profit, capitalism immediately appropriates it for its strengthening. In addition, the proliferation of opportunities and solutions to different problems people experience only serve as ruses for increased domination and axiomatization. After numbing the people's critical impulse, capitalism assiduously modifies and mutates itself in 
manifold domains by even fashioning redemptive possibilities, hence creating a vicious cycle of subjugation (see Michael Hardt and Antonio Negri 2000, 39).

The emancipatory component of capitalism is blemished by its concealed conservatism, systemic deception, and reactive tendency to reterritorialize into capture. This is the reason why Deleuze and Guattari $(1983,246)$ claim that capitalism is not the absolute limit of society despite its power to decode all symbolic codes. The lingering question about the limit of society remains. Their answer to the aforesaid query is schizophrenia. However, I deem it necessary to first distinguish the said concept with 'paranoia.'

As two kinds of subjectivity, paranoia and schizophrenia are molecular by-products of the interaction between desiring-production and anti-production. Because they are of less rigidified relational origins, they are not entirely estranged from the dynamic and open-ended characteristics of the syntheses of desire. Paranoia repels the aggressiveness of desiring-production. On the other hand, schizophrenia embraces the forces of production and anti-production affirmatively and radically. It pushes the belligerent forces of desiring-production to their limits by starting all over again from the first and second syntheses of desire toward the consummation of a nomadic subjectivity. As two poles of libidinal investments, additionally, paranoia arises from the processes of reterritorialization and recoding, hence representing the reactionary pole; while schizophrenia is an offshoot of deterritorialization and decoding, thus the schizoid revolutionary pole. As Deleuze and Guattari (1983,366-367) distinguish:

The two poles are defined, the one (paranoia) by the enslavement of production... the other (schizophrenia) by the inverse subordination and the overthrow of power. The one by these molar structured aggregates that crush singularities... the other by the molecular multiplicities of singularities... The one by the lines of integration and territorialization that arrest the flows ... the other by lines of escape that follow the decoded and deterritorialized flows, inventing their own nonfigurative ... schizzes that produce new flows, always breaching the ... territorialized limit that separates them from desiringproduction.

Schizophrenia deals with subjectivities characterized by molecular singularities, nomadic mobility, and creative flows. It is the social libidinal investment that legitimately utilizes the syntheses of desire where desire's polyvocal attributes are maintained and advanced. It is capable of subverting the molar norms engineered by Oedipus. Thus, schizophrenia is society's true limit and capitalism's greatest adversary. For Deleuze and Guattari $(1983,245)$ :

Hence one can say that schizophrenia is the exterior limit of capitalism itself or the conclusion of its deepest tendency, but that capitalism only functions on condition that it inhibit[s] this tendency, or ... displace[s] this limit, by substituting for it its own immanent 
relative limits, which it continually reproduces.... It axiomatizes with one hand what it decodes with the other. Such is the way one must reinterpret the Marxist law of the counteracting tendency. With the result that schizophrenia pervades the entire capitalist field from one end to the other. But for capitalism it is a question of binding the schizophrenic charges and energies into a world axiomatic that always opposes the revolutionary potential of decoded flows with new interior limits.

This is the reason why the nuclear family is deputized by the capitalist system to neutralize schizophrenia's revolutionary potentials. Specifically, the family is built as an avenue for capitalism to repress desire via psychoanalysis' Oedipal triangulation. In this manner, an interior limit to desire is crafted, which further pulls it up short of schizophrenia as an exterior limit (see Buchanan 2008, 116). But despite the radicality of schizophrenia, capitalism furtively configures its own ambivalent investment. On the one hand, it is its paranoiac because of its propensity to reterritorialize and recode; on the other, it is schizophrenic by virtue of its unavoidable tendency to deterritorialize and decode.

The schizophrenic character of capitalism installs its position in 'universal history' or what Marx calls as 'world history.' The etymology of the concept of universal history is indebted to Marx's use of the term in Grundrisse (1973). World history is merely a result, not something that exists a priori (see Deleuze and Guattari 1983, 109). As described by Marx $(1973,105)$, it becomes a result when labor's abstract category gains the status of a 'practical truth as an abstraction' only with capitalism. Schizophrenia only occurs at the end of history. This event engenders capitalism to unleash what it privatized and separated, that is the inextricable link or common quiddity of desire and labor. The schizophrenization of capitalism emancipates desiring-production from the estranging fetters of social production. In this regard, desiring-production fuels a 'permanent revolution' or diagrams a 'new earth,' which is a movement of unceasing differentiation and creativity. Such disclosure not only deletes the egotistical-oriented chasm configured by capitalism to police the rhizomic movement of desire, but it also allows capitalism to perform its autocritique. For Deleuze and Guattari (1983, 270), "capitalism is without doubt the universal of every society, but only in so far as it is capable of carrying to a certain point its own critique ... the critique of the processes by which it re-enslaves what within it tends to free itself or appear freely." Thus, capitalism leads us to a brand of universal history where values are no longer externally determined by objects. Through world or universal history, objects assume values by virtue of subjective labor or human activities (i.e., economic, artistic, and political).

Nevertheless, the subordination of objects to the subjective value-giving leads to another external subordination, and this time, it is authored by capitalism. In Freudian philosophy, polymorphous desire is bi-univocalized via the Oedipus complex or privatized in the nuclear family. In the capitalist system, the deterritorialized subjective essence of activity in general reterritorializes by means of privatization (see Deleuze and Guattari 
1983, 270). Whereas Marx criticizes political economy's privatization of capital in pursuit of free wage-labor, Nietzsche criticizes modernity's nihilism to de-deify nature and bring us to a life of affirmation and becoming. Meanwhile, Deleuze and Guattari criticize traditional psychoanalysis to unshackle desire from the restraining confines of Oedipus.

In Marxist philosophy, production as a dynamic and self-sustaining human activity serves as a human universal. This indispensably informs Deleuze and Guattari's formulation of the schizoanalytic notion of universal history. Production, in the DeleuzoGuattarian context, is a difference-engine irreducible from all forms of capture or representation. Paradoxically, the market in the capitalist system both serves as the fulcrum of all operations and the difference-engine. It perpetually fashions a differential network of relations despite the fact that "capital extracts its surplus from the differential flows enabled by this network, by means of exploitation and the never-ending repayment of an infinite debt" (Adrian Parr 2001, 43). Although capitalism falls short in realizing universal history, it inaugurates the potentiality for such a kind of history because of its differential capacity. Capitalism's shortcoming inspires schizophrenia's principal goal of freeing capital from the narcissistic and oppressive machinery of the market. Through schizophrenia, difference is creatively and dynamically proliferated toward the virtual realization of permanent revolution or critical freedom immanent in universal history.

Universal history's concern is the molecular unconscious of the individual as biological life-form - the perpetual reproduction and transformation of life a la Nietzsche and Spinoza (see Holland 1999, 95). In Anti-Oedipus, the molecular unconscious serves as the principle of freedom and difference. In its schizophrenization, capitalism deterritorializes the domains of the consciousness and representation to liberate this molecular unconscious from the objective brand of estrangement provided by savagery and despotism. But as I noted previously, the deterritorializing force of capitalist production is always expelled by decadent reterritorializations that subject desire to the mechanism of Oedipus (capital).

Through schizoanalysis, capitalism is subjected to self-critique that further leads to the virtuality of a permanent revolution. This brand of revolution eradicates power and paranoia to allow the rhizomic movement of schizophrenia, thereby subordinating molar libidinal investments to molecular ones (see Holland 1999, 95). Additionally, permanent revolution brings us to an alliance-oriented network of societal relations diverse from savagery and despotism. The 'free-market' produced in this mode of social production crafts transversal and participatory alliances freed from the fetters of infinite debt, as well as monopolized death and expenditure. In this vein, all market alliances revolve around the principles of freedom, opportunity, and molecular libidinal investments. Similarly, molecular kind of deterritorialization and decoding subordinates molar reterritorialization and recoding.

The critical diagnoses of Oedipus and capitalism form the first major phase of Anti-Oedipus' schizoanalytic project. The next phase involves a critique of the various manifestations of reterritorialization, recoding, and paranoia in society. Outside the constricted and capitalist-maneuvered realm of the nuclear family, schizoanalytic critique is likewise directed toward the larger societal milieu where asceticism, Oedipality, and 
capitalism interweave through the numerous networks of molar investments that polarize the productive and creative capabilities of desire or desiring-production.

The third thesis of schizoanalysis deals with the "the non-familial libidinal investments of the unconscious have primacy over the familial investments of the unconscious" (Deleuze and Guattari 1983,356). These social investments are more primary than those conditioned under the nuclear family. Oedipus is instrumental in traditional psychoanalysis and capitalism's homegenization of subjectivity-formation in the nuclear family. As such, Oedipus cannot be perceived as a determining principle of anything social. If Oedipus is to be analyzed in relation to societal investments, it is in the form of a reduction or blockage of societal flows into personalized images of "paranoiac type of territoriality" (Deleuze and Guattari 1983, 278). It is determined by paranoiac territoriality and investments in society through capitalist reterritorialization. Because of this process, paranoiac investments are further applied to the nuclear family. In society, the flows of social investments forbid individuals to reappropriate the collective products of their labor and prohibit them from murdering their boss. As paranoiac flows are invested in the nuclear family, it translates into more stringent proscriptions to antagonize the father, and to reappropriate your mother, including your siblings.

The paranoia that capitalism imposes upon Oedipus can find its expression in myth and tragedy (see Deleuze and Guattari 1983, 304). As such, Oedipus appears as a universal fantasy (Michel Foucault 1970, 208-211). The consolidation of capitalism, myth, tragedy, and Oedipus serves as a principle of representation that captures desiringproduction's critico-creative relation to social production. Schizoanalysis repudiates a representationalist and belief-oriented unconscious. Representation and beliefs halt and fixate desire's proclivity toward unceasing connections that further breed subjectivity-formations and constellations. Paranoiac territoriality prepares the unconscious for conscious yet nonconcrete capture. Regardless of this possibility, desire remains irreducible to the bi-univocalized representation of conscious prohibition. In other words, the clamor for an overarching principle that would ground all things, and more importantly, would univocalize the rhizomic character of life, diverges from capitalism's axiomatization of everything in the contemporary period. Beliefs of paranoiac social or molar investments segregate, privilege, and restrict molecular investments of desiring-production.

Capitalism's repressive paranoiac investments informs the revolutionary project of schizoanalysis that aims to differentialize, if not dismantle, the citadel and networks of representation in society and the family such as debt to capital, Oedipus complex, and various kinds of ideologies like fundamentalism and fanaticism. The negative task of schizoanalysis, as Deleuze and Guattari articulate, "goes by way of destruction - a whole scouring of the unconscious, a complete curettage. "Destroy Oedipus, the illusion of the ego, the puppet of the superego, guilt, the law, castration" (Deleuze and Guattari 1983,311).

The negative task of schizoanalysis is accompanied by its positive task. Affirmatively, it undoes molar recoding so that it would be subordinated to molecular 
investments. The process of undoing, however, is always subjected to deterritorialization and reterritorialization; that is why, an utter emancipation from molar organization is neither necessary nor possible (see Holland 1999, 98). In relation to the State, schizoanalysis must undo molar organizations so that they would be subordinated to molecular activities and relations. In other words, schizoanalysis differentializes molar investments in order to mightily express the rhizomic dynamicity of the molecular unconscious. Schizoanalysis' social embeddedness shapes its goal of locating captured desiring-machines and reinstating their primordial molecularity. Such a quest is premised on the cognizance of the operations, syntheses, and becomings of the subject's desiringmachines. In short, schizoanalysis' positive task:

... [C]annot be separated from ... the destruction of the molar aggregates, the structure $\mathrm{s}$ and representations that prevent the machine from functioning. It is not easy to rediscover the moleculeseven the giant molecule-their paths, their zones of presence, and their own syntheses amid the large accumulations that fill the preconscious, and that delegate their representatives in the unconscious itself, thereby immobilizing the machines, silencing them, trapping them, sabotaging them, cornering them, holding them fast (Deleuze and Guattari 1983,338).

Both negative and positive tasks of schizoanalysis comprise its therapeutic component. The subversion of molar investments engenders the discovery of molecular investments capacitated to free individuals from the paranoiac territoriality imposed by Oedipus and capitalist recoding via the nuclear family and capitalist private ownership. The discovery of molecular investments and freedom of subjects from paranoia is a form of "immanent schizo-law ... that will dismantle all the assemblages of the paranoiac law" (Deleuze and Guattari 1986, 60). Likewise, through molecular investments, the free-form of schizophrenia, fashioned by market decoding, is cultivated and endorsed.

\section{DESIRE'S MOLECULARIZATION AND REVOLUTIONARY TRANSFORMATION}

From the nuclear family to the society, schizonalysis aims to reinstate desire's molecularized pragmatics. The important link connecting the familial space to the larger societal sphere highlights the vital relation between libidinal and social investments. The inseparability between these two spaces is akin to schizoanalysis' therapeutic and revolutionary components.

In trying to associate the concept "revolution" with the notion of schizoanalysis, which Deleuze and Guattari draw from psychoanalysis and Marxism, the value of Nietzschean philosophy must also not be overlooked. Perhaps, the discussion on revolution is the very moment where schizoanalysis partially distantiates itself from Marxism to give way to Nietzschean philosophy. Primarily, while it is true that desire is 
the driving principle of schizoanalysis, it lacks a determinate role in Marxism. A paramount role is associated with desire because it is constituted in the social infrastructure in the same manner that it can liberate such territoriality from its capitalist seizure. The combination of Freudian and Nietzschean terminologies comprise schizoanalytic revolution's anti-capitalist/ascetic postures - derivative of desire, not of a particular interest (be it class-related or of nationalist cause). Deleuze and Guattari $(1983,344)$ believe that: "Revolutionaries often forget, or do not like to recognize, that one wants and makes revolution out of desire, not duty. Here as elsewhere, the concept of ideology is an execrable concept that hides the real problems."

Despite desire's social embeddedness and rhizomic attributes, contemporary capitalism initiates an ethical and molecular brand of fascism. As it calibrates itself to axiomatize desiring-production, capitalism creatively persuades subjects to blindly submit themselves to oppression. Given that all societal machines such as nations and states are presently totalized by capitalism, schizoanalytic revolution therefore is confronted by an enormous challenge to overcome these repressive machines so as to resurrect desire's creative capacities.

Furthermore, schizoanalytic or permanent revolution is concerned with the nonteleological production of nomadic subjectivities, connections, and intensities. It deals with "schizophrenia as a process," not with the schizophrenic (schizo) as a psychoanalytic entity. Deleuzeand Guattari $(1983,341)$ clarify thisclaim in Anti-Oedipus:

There is a whole world of difference between the schizo and the revolutionary: the difference between the one who escapes, and the one who knows how to make what he is escaping escape, collapsing a filthy drainage pipe, causing a deluge to break loose, liberating a flow, resecting a schizo The schizo is not revolutionary, but the schizophrenic process-in terms of which the schizo is merely the interruption, or the continuation in the void-is the potential for revolution.

Schizophrenia as a process bears the revolutionary potential. It conditions the possibility of polyvocal desire capacitated in undoing and subverting the capitalist system - the author of wide-scale power-manipulation and paranoia in society. As a revolutionary potential, the schizophrenic process can undermine molar investments in society in the same manner that it can anytime be vitiated or immobilized by suppressive forces.

In reference to the Nietzschean concept of the will to power, Deleuze in Nietzsche and Philosophy (1983) explicates that one of the foremost misinterpretations of the concept of the will to power is its appropriation as a clamor for power and the desire for domination. ${ }^{13}$ In Nietzschean philosophy, only the slaves desire for power because they view it as something external to the will. Deleuze asserts that there is a difference between power as an object of desire and power as an indicator of the will's quality. On the contrary, Nietzsche prefers the latter because he ponders the will to power as the differential element of forces. ${ }^{14}$ 
Of course, the inclusion of the term telos in discussing schizoanalysis appears to be a contradiction. The subject, for both Nietzsche and Deleuze, is merely a conduit to desire's rhizomic motion and an assemblage of forces whose attributes are not immutable and final. In short, there is no subject who desires or wills. Meanwhile, subjecting desire to a predetermined telos is tantamount to annihilating its creative abilities. Because a goal or end lacks a positive place in schizoanalysis, it can be claimed that schizoanalysis is devoid of any political objective to propose, including a singular voice to articulate the masses' sentiments (see Deleuze and Guattari 1983,380). Positing a definitve telos is problematic because it disregards the contingencies of social materialities, as well as the mapping of new possibilities or virtualities. Classical Marxism educates us on how the overvalorization of the telos of a classless society leads to its perdition. For schizoanalysis, becoming reductively teleological voids the very nature of the schizophrenic as a process and homogenizes the molecular heterogeneity of desire.

The schizophrenic process of schizoanalytic or permanent revolution is irreducible to any teleological and molar representation. It necessitates a complex reversal of values wherein desiring-production overrides capitalist social production by nullifying its relatively impervious sovereignty and asceticism. The cessation of capitalism's pedigree over desiring-production obliterates among individuals their paranoia of infinite debt to capital and the enormity of filiation-laden societal relation. The performance of this intrepid yet perilous task requires us to initially learn from Hitler's rhetoric of fascism that effectively manipulated the masses' desire. Meaning to say, the axiomatic language of capitalism must be studied and analyzed carefully, that is, in cultivating itself as a creative and regulative machinery capable of generating political, cultural, economic, and social productive forces between different societal organizations and structures. Grasping comprehensively the axiomatized language of capitalism is succeeded by the project of calibrating the socius to fashion productive forces whose efficient cause is an alternative to capitalist representation. Capitalism, indubitably, is capacitated to craft productive forces in the socius. Nevertheless, such creativity also manifests as exploitation of resources, which further oppresses the community and nature. The productive forces fashioned in the socius characterize a novel mode of social production - the 'new earth' or permanent revolution. Deleuze and Guattari $(1983,299)$ are quick to warn individuals that this "new world can only be bodied forth in so far as it is conceived. And to conceive there must first be desire."

The formulation of a nonteleological revolutionary project leads us to the second thesis of schizoanalysis: "There are two types of social investments: there is the unconscious libidinal investment of group or desire and the preconscious investment of class or interest" (Deleuze and Guattari 1983, 343). The latter is only of secondary significance as compared with the former, because our interests are merely caused by the unconscious libidinal investments of desire. Such invest a degree of development of forces (see Holland 1999, 102). The capitalist system's radical power to subvert conventional molar representations and frontiers of power relatively opens its doors for us to access capital's productive forces. However, in the long run, such accessibility can transform into a ploy for increased axiomatization, accumulation, and fortification. 
Take the case of independent films. The creative, subversive, and subcultural contents and forms of these films penetrate the hegemonized body of the mainstream film industry to reinstate its molecularity. One of the most notable quandaries that confront these films, especially after receiving both global and national acclaims, is the possibility of being commodified by capitalism. The commodification and techno-mechanical reproduction of Independent Films in particular, and arts in general, destroy their aura (auratic character), and thereby contributing to the numbing of people's critical or revolutionary consciousness on one hand, and the fortification of capitalism on the other(Benjamin 2007, 217-252).

Going back to Deleuze and Guattari's problematization of ethical fascism, it must be clarified that the masses are not deceived in the same way that a typical marketing product deceives a customer because of the product's fabricated attributes. They are not deceived by capitalist ideologies; rather, their desire is engrossed by an exploitative social investment that instills in their consciousness the utopia of greater freedom and productivity of forces. Their uncritical consciousness and voluntary exploitation are undeniably conditioned by a submission to the very system that would annihilate their critical impulse and repress desire's creativity. The crucial question that must be the object of critical attention is not what kind of revolution should the masses formulate, but what conditions that interest (see Holland 1999, 103). This occurs when despite their perceived coexistence, preconscious investments are substantially revolutionary and molecularized, yet formally repressive and molarized.

The Leninist version of Marxism is an appropriate example of this said problematic. Its preconscious investment is indeed revolutionary, specifically in relation to its goal of liberating the proletariats from capitalist domination. However, the prejudiced inclusion of the role of the Communist party posterior to the worker's upheaval subjects this dejected collectivity to a relatively vicious cycle of domination. Anti-Oedipus alludes to this problematic: "a group can be revolutionary from the standpoint of class interest and its preconscious investments ... and even remains fascist and police-likeÆfrom the standpoint of libidinal investments" (Deleuze and Guattari 1983, 348).

The coexistence of libidinal and preconscious investments, and the possibility of their noncoincident occurrence is presupposed in Deleuze and Guattari's distinction between the two kinds of revolutionary rupture, namely 'preconscious' and 'libidinal.' The former labors for the actualization of new socius constitutive of novel objectives, polarizations, and schemes of power. One may rapidly think of the revolutionary rupture capitalism instigated against despotism via the axiomatization of old symbolic codes and its legacy of emancipating the molecular unconscious from objective estrangement. Capitalism's calculative logic incessantly axiomatizes everything and craft ever-renewed productive forces and relations of power in pursuit of massive and interminable expansion.

Nevertheless, Deleuze and Guattari maintain a critical stance on the concept of capitalism as a new socius. Principally, it is insufficient for the libido to invest in a new socius based on the novel goals and codifications projected by the preconscious revolutionary rupture. Moreover, the new social body can be immediately recoded and 
reterritorialized by capitalism in the market. Meanwhile, the libidinal revolutionary rupture aspires for the promotion of molecular desire that subverts or differentializes molar codifications in society. Because these kinds of revolutionary rupture function diversely, Deleuze and Guattari $(1983,375)$ opine that "there can be a preconscious revolutionary break, with no real libidinal and unconscious revolutionary break. Or rather ... there is first a real libidinal revolutionary break, which then shifts into the position of a simple revolutionary break with regard to aims and interests, and finally re-forms a merely specific reterritoriality, a specific body on the full body of capital." Unless these revolutionary ruptures coincide actively, then a permanent revolution would remain inconceivable and impracticable. Meaning to say, the configuration of a new socius must be critically accompanied by the molecularization of desire and an undermining of all molar representations.

The molecularization of molar codifications and the maximization of desiringproduction in society entail a break from causal determinations authored by capitalist axiomatization. The said rupture underscores the idea that the cause of revolutionary struggles is indissolubly associated with the oppressive and the marginalized classes. In this vein, from the question about the factors that make the revolution conceivable and practicable, the paramount issue transforms into the relationship between these revolutionary ruptures and the estranged masses, which Deleuze and Guattari (1983, 377) describe as the "weakest links of a certain social system."

\section{PERMANENT REVOLUTION AND THE TWO KINDS OF GROUP-FORMATION}

Desire's status in the socius, whether it can be molecularized via permanent revolution or captured through capitalist reterritorialization, is defined by its relation to the two kinds of collectivity or group-formation, namely the 'subject group' and the 'subjugated group' (Deleuze and Guattari 1983, 256). The presence of these groups adheres to the concept of differenciation. As the second part of the Deleuzian principle of difference, differenciation is the actualization of multiplicity in material occurrences and state of affairs (Patton 2000,38). In the context of schizoanalysis, differenciation is reflected through the two kinds of group-formation that prosecute revolution. Furthermore, the aforesaid kinds of group-formation are very much related to the schizophrenic and paranoiac libidinal investments, respectively. Specifically, the operation of the former is grounded on schizophrenic libidinal investments, while the latter is based on paranoiac preconscious investment. Deleuze and Guattari (1983,366-367) note:

The two poles are defined, the one by the enslavement of production and the desiring-machines to the gregarious aggregates that they constitute on a large scale under a given form of sovereignty; the other by the inverse subordination and the overthrow of power. The one by these molar structured aggregates that crush singularities, select them, and regularize those they retain in codes or axiomatics; the other by the molecular multiplicities of singularities that on the 
contrary treat the large aggregates as so many useful materials for their own elaborations. The one by the lines of integration and territorialization that arrest the flows ... break them according to the limits interior to the system ... the other by lines of escape that follow the decoded and deterritorialized flows, inventing their own nonfigurative ... schizzes that produce new flows, always breaching the ... territorialized limit that separates them from desiring-production.

The two kinds of group-formation are dynamic and typological categories. What I mean by dynamic is that at a particular revolutionary event, one group may transition from one group-formation to the other. Likewise, a revolutionary movement can be carried out, characterized by a hybridity or an oscillation between the schizophrenic and the paranoiac investments - albeit Deleuze and Guattari clarify that such oscillation privileges the former over the latter. Meanwhile, I describe these categories as typological because despite both groups' capability to launch a revolution, the subjugated group, for example, merely operates within preconscious investments. Political organizations tend to repress desire's productivity - although this is not tantamount to their sheer rejection of vanguard parties' existence. Internally, these parties function as a subject group. But their articulation of the masses' sentiments or interests inevitably redounds to the conversion of these people into a subjugated group. ${ }^{15}$

Despite the coexistence of the two kinds of social investments and revolutionary rupture, an unconscious revolutionary rupture can only be sustained through an unwaveringly schizophrenic libidinal investment. The problem with the paranoiac preconscious investment is that its hierarchical mechanism merely produces homogeneous identities and reactive forces, as well as halts desire's molecularization. Although a revolutionary preconscious investment succeeds by utterly nourishing a paranoiac investment 'libidinally,' desiring-production and the actualization of its novel socius remain subordinated to "higher interests of the revolution and the inevitable sequences of causality" (Deleuze and Guattari 1983, 378). In this vein, permanent revolution can only be prosecuted by the subject-groups via the revolutionary rupture provided by schizophrenic libidinal investment. As Deleuze and Guattari (1983, 379-380) defend: "The schizophrenic process ... is revolutionary in the very sense that the paranoiac method is reactionary and fascist; and it is not these psychiatric categories, freed of all familialism, that will allow us to understand the politico-economic determinations, but exactly the opposite."

As a process of libidinal investment, schizophrenia empowers subject-groups to optimize the productive forces released by capitalism. The creative utilization of the decoded and reterritorialized flows crafted by capitalism prevents these active forces from being recoded and reterritorialized by capitalism itself, toward the fortification of its autoproductive and axiomatic system. The ideal consequence is achieved when the subject-groups fashion a revolutionary line of escape (see Deleuze and Guattari 1983, 377). The said line of escape subverts the capitalist-authored codifications while in the process of escaping them, at least tentatively because subversion can easily be recoded 
and reterritorialized by capitalism or any dominant system (see Holland 1999, 104). Take the case of Negri's theorization of the Autonomia. Informed by the capitalist axiomatization of all human activities and values in the entire society, the undermining of capitalist society no longer revolves around the structure of the factory but around the radical organization of social relations (Negri 1984, xix-xxxiz). The Autonomia movement's initial phase is characterized by optimism and radicalism. It appropriates the overwhelming potency of capitalism in the age of globalization by formulating novel kinds of transnational solidarities and minoritarian subversions capable of confronting hegemonic global forces and mechanisms, specifically the capitalist system. The movement's guerilla-like activities and communication processes bear close affinity with the Deleuzo-Guttarian concept of subject-groups. But again, we should not forget that these revolutionary collectivities always face the predicament of perpetrating more hierarchical relations and being totalized by capitalism.

In Deleuze and Guattari's time, the French Communist Party serves as the actualization of the axiomatization of the workers' movements. We may even think that the United Nations Organization is also a product of this repressive process, where, in seeking to reconcile all cultural differences, commits violence to different societies, races, religions, and ethnicities. Capitalism induces subject-groups to risk being complemented by preconscious revolutionary rupture just to augment their deterritorializing and decoding proficiencies. But vigilance should always be observed because this is merely a ploy that can vitiate our radical efforts leading to another brand of exploitation or totalization. As such, the revolutionary actors inopportunely convert into subjugated groups, if not subjected to disbanding. This is the reason why the subjugatedgroup serves as a familiar territory for Oedipalized subjects in the nuclear family (see Holland 1999, 105). It is because Oedipus is not only a familial phenomenon. Outside the paranoiac territoriality of the nuclear family, Deleuze and Guattari $(1983,103)$ elucidate:

... [It] provides a means of integration into the group.... Oedipus also flourishes in subjugated groups, where an established order is invested through the group's own repressive forms. And it is not the forms of the subjugated group that depend on Oedipal projections and identifications, but the reverse: it is Oedipal applications that depend on the determinations of the subjugated group as an aggregate of departure and on their libidinal investments.

Given these challenging circumstances, an unconscious revolutionary sensibility develops in subject groups. The ubiquity of capitalism influences the enormous presence of subjugated groups and paranoiac investments. But we must not be oblivious to the fact that it is also in capitalism's very system that its catalysts (decoding and deterritorialization) are unleashed. This critical moment of immanent contradiction renders the inexorable possibility of schizoanalytic revolution. Its paramount objective is to bolster and intensify deterritorialization and decoding's subversive force that would fuel the affirmative metamorphosis of subjugated groups into subject-groups. Moreover, 
it aspires to assemble its desiring-machines and subject-groups in the subaltern regime of society in order to reinstate its molecular networks, amplify its value and strength, and undermine the capitalist power-structure.

\section{CONCLUSION}

Schizoanalysis seeks to liberate desiring-production from its Oedipal biunivocalization in the nuclear family, and capitalist repression. In doing so, it empowers desire to create, recreate, and engage into various libidinal and social investments. Likewise, it transforms the subject into a dynamic and radical assemblage. It is dynamic, in the sense that its attributes are never hierarchical, fixed, and slavish, and radical because it bears the ability to undermine all kinds of Oedipalized, capitalist, and molar codifications in the individual, family, and society. But for Deleuze and Guattari, it is only the subject group-formation, a collectivity with no definitive labels and a priori attributes that can creatively and critically initiate the molecularization of desire and the schizophrenization of all socio-libidinal investments.

Despite the radicality of schizoanalysis, it merely remains as one of the many paths of therapeutic and revolutionary transformation in the Deleuzo-Guattarian philosophy. In $A$ Thousand Plateaus, for example, the revolution-to-come is articulated, among others, via the principles of becoming-minoritarian and/or becoming-democracy. Familiarizing ourselves with the other expressions of revolution-to-come allows us to have a holistic understanding of Deleuze and Guattari's philosophy whose principal thrust is the tireless creation of new concepts and relations capable of critically diagnosing oppressive systems and principles at present.

\section{NOTES}

1. Deleuze and Guattari differentiate micropolitics (molecular) from macropolitics (molar). Whereas the former is based on heterogeneous investments and local connections, the latter is based on homogeneous codifications and hierarchical (arborescent) relations.

2. In A thousand plateaus, Deleuze and Guattari $(1987, \mathrm{xi})$ write: "For many French intellectuals, the hyperactivism of post-May gave way to a mid-seventies slump, then a return to religion or political conservatism in a foreshadowing of the Reagan eighties."

3. Conceiving desire as a lack subordinates it to need. However, needs are derived from desire: "they are counter-products within the real that desire produces. Lack is a counter-effect of desire.... Desire always remains in close touch with the conditions of objective existence" (Deleuze and Guattari 1983, 28).

4. State philosophy or representationalist thinking characterizes "Western metaphysics since Plato... It reposes on a double identity: of the thinking subject, and of the concepts it creates and to which it lends its own presumed attributes of sameness and constancy. The subject, its concepts, and also the objects in the world to which the concepts are applied have a shared, internal essence: the self-resemblance at the basis of identity. Representational thought is analogical; its concern is to establish a correspondence between these symmetrically structured domains (Deleuze and Guattari 1987, xi). 
5. The restoration of difference, earlier developed by Deleuze in Difference and Repetition (1994), plays a vital role in the reconstruction of the Freudian death instinct and the concept of repetition. The restoration of difference obliterates the pedigree of identity over difference in Western philosophy. The restored primacy of difference eventually transfigures the concept of 'repetition.' A materialist philosophy of difference espouses a recurrence of difference, which further critiques Freud's identitarian conceptualization of repetition. The compulsion to repeat, as Sigmund Freud (1961, xiv) asserts qualifies pleasure to be a principle of psychic life. However, because this coercion for repetition is grounded on the death instinct, it redounds into a mechanical return to identity - a state of incarceration in stasis, fixation, and neurosis. As regards the first synthesis, being recurrently fixated to a certain connection is unproductive, that is why they propose for a differentialization of repetition in psychic life.

6. See Antonin Artaud, "To Have Done With the Judgment of God," http:// www. 1 abster 8 . net/w p - c ontent/uploads/2015/08/ArtaudToHaveDoneWithJudgementofGod.pdf. Accessed May 31, 2018.

7. Freud's understanding of 'primal repression' converges with Deleuze and Guattari's anti-production. Insofar as psychic repression is defined by societal oppression and repression, both kinds of repression are products of primal repression (see Deleuze and Guattari 1983, 184, 339).

8. See also Holland 1999, 33. Catatonics are pauperized by Oedipus as "they become immobile, silent, they retreat to the body without organs ... where all desiring-production is arrested" (Deleuze and Guattari 1983, 135-136). My utmost gratitude to Eugene Holland. His book, Deleuze and Guattari's anti-oedipus: introduction to schizoanalysis, significantly contributed to my reconstruction of Deleuze and Guattari's schizoanalysis.

9. The concept paralogism reminds us of Kant's 'paralogism of pure reason.' Deleuze and Guattari discusses in Anti-Oedipus $(1983,74,79,101,114,127)$ the paralogism of extraposition, paralogism of the double bind, paralogism of biunivocal application, paralogism of displacement, and the paralogism of the afterward.

10. For Deleuze and Guattari $(1983,114)$, "The law tells us: You will not marry your mother, and you will not kill your father. And we docile subjects say to ourselves: so that's what I wanted!"

11. The subject or the child then fail to realize that "the father and the mother exist only as fragments, and are never organized into a figure or a structure able both to represent the unconscious, and to represent in it the various agents of the collectivity" (Deleuze and Guattari 1983, 97).

12. It is vital to recognize Lacan's effort to depersonalize psychoanalysis. He claims that the Oedipus complex is concerned only apparently with the concrete figures of the father and the mother (Holland 1999, 42). Regardless of Lacanian philosophy's importance to the current discussion, its distinction between the Imaginary and the Symbolic is marred by exclusivism. Hence, the Lacanian theorization also commits the paralogism of the double-impasse.

13. See Walter Kaufmann 1974, 284-306.

14. If ever the will clamors for something, it desires for something immanent to itself. 
For Deleuze $(1983,78)$, "What the will wants... is to affirm its difference or to deny what differs."

15. Deleuze and Guattari's critical distance from vanguardism directs us to alternative political organizations, which are less arboreal and centralized in the likes of the autogestion in France, as well as the autonomia in Italy.

\section{R E F E R E N C E S}

Artaud, Antonin 2015Artaud, "To Have Done With the Judgment of God," http:// www.labster 8 .net/wp-content/uploads/2015/08/ArtaudToHaveDoneWithJudgementofGod.pdf. Accessed May 31, 2018.

Benjamin, Walter. 2007. Illuminations: essays and reflections. New York: Schocken Books. Buchanan, Ian. 2008. Deleuze and Guattari's anti-oedipus. a reader's guide. New York: Continuum.

Deleuze, Gilles. 1983. Nietzsche and philosophy. Translated by Hugh Tomlinson. London: Athlone Press. . 1990. The logic of sense. Translated by Mark Lester with Charles Stivale, Constantin Boundas eds. New York: Columbia University Press. . 1994. Difference and repetition. Translated by Paul Patton. New York: Columbia University Press. . 1995. Negotiations. Translated by Martin Joughin. New York: Columbia University Press, 1995.

Deleuze, Gilles and Guattari, Felix. 1983. Anti-oedipus: capitalism and schizophrenia. Translated by Robert Hurley, Mark Seem, and Helen R. Lane. Minneapolis: University of Minnesota Press. 1986. Kafka: towards a minor literature. Translated by Dana Polan (Minneapolis, University of Minnesota Press. . 1987. A thousand plateaus: capitalism and schizophrenia. Translated by

Brian Massumi. Minneapolis: University of Minnesota Press. . 1994. What is philosophy? Translated by Hugh Tomlinson and Graham Burchell. New York: Columbia University Press.

Foucault, Michel. 1970. The order of things: an archaeology of the human sciences. London: Tavistock.

Hardt, Michael and Negri, Antonio. 2000. Empire. Cambridge: Harvard University Press.

Holland, Eugene. 1999. Deleuze and Guattari's anti-oedipus: introduction to schizoanalysis. New York: Routledge.

Kaufmann, Walter. 1974. Nietzsche: philosopher, psychologist, anti-Christ. New Jersey: Princeton University Press.

Marx, Karl. 1973. Grundrisse: introduction to the critique of political economy. New York: Vintage.

Negri, Antonio. 1984. Marx beyond Marx: lessons from the grundrisse. Translated by H. Cleaver, M. Ryan, and M. Viano. New York: Bergin \& Garvey.

Patton, Paul. 2000. Deleuze and the political. London: Routledge.

Submitted: 21 February 2018; revised: 18 October 2019. 